\title{
Problems of Implementing Innovative Solutions in the Construction Sector of Economy Organizations
}

\author{
Maria Rakhova* and Svetlana Nikonorova \\ Vladimir State University named after Alexander and Nikolay Stoletovs, Associate Professor of the \\ Department of Economics, Investment and Innovation Management, 600005 Vladimir Region, \\ Vladimir, Gorkogo str, 79, Russian Federation
}

\begin{abstract}
The subject of research in the following article is innovative solutions in organizations which are engaged in construction activity, their importance for development and increase in socio-economic indexes. In order to assess the level of innovativeness of the regional economy of the central federal district of the Russian Federation, the survey presents the dynamics of the innovation development rating of the subjects (according to the ISIEZ of the HSE). The importance of development and introduction of innovations are reflected in the construction sector of economy. As the subject of detailed research in this article, the enterprises of the Vladimir region, implementing innovative projects and development, and also dynamics of indicators of their functioning, are considered. Survey conducted within the research has allowed to allocate and group the main reasons for low innovative activity of the construction enterprises.
\end{abstract}

\section{Introduction}

Solving the problem of radical increase in efficiency of the Russian economy, it is necessary to create incentives and conditions for the promotion of a number of areas. One of such areas is the formation of innovative systems. Implementation of the innovative scenario demands maximum efforts from the state and business in each territorial subject of the Russian Federation. Considering a question of use of innovative technologies in all types of economic activity, it is necessary to address the history of of the term's "innovations" appearance once again.

\section{Methods}

The concept "innovation" has been entered into economic science by Josef Schumpeter in the work "The theory of economic development" (1911). Innovation was considered by the author as a mean of overcoming economic crises [1] which is shown in creation of new

\footnotetext{
* Corresponding author:
} 
goods or new quality of goods, a new method of production; opening of the new market or a new source of factors of production and also in creating a new organization of a sector.

At the moment you can find several definitions of this definition, which slightly differ from the initial. For example, according to the dictionary of economic terms [2], innovation is the investment of capital in economy providing change of the equipment and technology or the new equipment, the technology which is the result of achievements of scientific and technical progress. We will note that the defining factor of an innovation is the development of invention, rationalization, appearance of big discoveries. According to the above, the questions concerning innovative development in all social and economic spheres of the state are still relevant.

In order to assess the level of innovation in the economy of the regions we will provide data from the Institute of statistical research and economy of knowledge (ISIEZ) of the National research university "Higher School of Economics" (Higher School of Economics National Research University), that issues the rating of innovative development of the Russian Federation subjects which cornerstone the system of quantitative and quality indicators of innovative development of regions is [3]. According to this technique all regions are ranged on indicators of innovative activity and also social and economic conditions, scientific and technical potential and quality of innovative policy. Ranging the regions of the Central Federal District (CFD) according to this rating is presented in table 1.

Table 1. Ranging the regions of the Central Federal District according to the Russian regional innovative index in 2014-2015.

\begin{tabular}{|l|c|c|c|c|c|c|}
\hline $\begin{array}{l}\text { Territorial subject of } \\
\text { the federation }\end{array}$ & $\begin{array}{c}\text { The place of the region in } \\
\text { general across the Russian } \\
\text { Federation }\end{array}$ & \multicolumn{2}{c|}{$\begin{array}{c}\text { The Place of the region } \\
\text { across the CFD }\end{array}$} & \multicolumn{2}{c|}{$\begin{array}{c}\text { Change of rating } \\
2015 / 2014\end{array}$} \\
\cline { 2 - 8 } & 2014 & 2015 & 2014 & 2015 & RF & CFD \\
\hline Moscow & 2 & 2 & 1 & 1 & 0 & 0 \\
\hline Kaluga region & 5 & 6 & 2 & 2 & -1 & 0 \\
\hline Moscow region & 17 & 14 & 4 & 3 & 3 & 1 \\
\hline Voronezh region & 20 & 15 & 5 & 4 & 5 & 1 \\
\hline Lipetsk region & 14 & 16 & 3 & 5 & -2 & -2 \\
\hline Belgorod region & 24 & 18 & 7 & 6 & 6 & 1 \\
\hline Tambov region & 27 & 25 & 8 & 7 & 2 & 1 \\
\hline Yaroslavl region & 22 & 28 & 6 & 8 & -6 & -2 \\
\hline Tver region & 29 & 32 & 10 & 9 & -3 & 1 \\
\hline Tula region & 42 & 37 & 12 & 10 & 5 & 2 \\
\hline Kursk region & 28 & 42 & 9 & 11 & -14 & -2 \\
\hline Vladimir region & 35 & 43 & 11 & 12 & -8 & -1 \\
\hline Ryazan region & 46 & 45 & 14 & 13 & 1 & 1 \\
\hline Bryansk region & 59 & 47 & 15 & 14 & 12 & 1 \\
\hline Smolensk region & 45 & 56 & 13 & 15 & -11 & -2 \\
\hline Ivanovo region & 64 & 57 & 16 & 16 & 7 & 0 \\
\hline Oryol region & 65 & 60 & 17 & 17 & 5 & 0 \\
\hline Kostroma region & 75 & 76 & 18 & 18 & -1 & 0 \\
\hline
\end{tabular}

The most significant changes all in all in the rating of regions (up to 14 points loss) to a negative side have happened in the Vladimir, Smolensk and Kursk regions, to positive - in the Bryansk region ( +12 points). Authors of this research note that regions of Russia are characterized by unevenness of development of various aspects of innovative processes and the factors influencing them, showing in this regard an essential variety. So, at the majority of regions of the CFD indexes of quality of innovative policy and the level of innovative activity, which is characterized by indicators of innovative activity of the organizations, effectiveness of innovative activity, costs of technological innovations, small innovative business, are very low. 
We will draw your attention to the above-mentioned characteristics, reflecting the type of activity called "Construction", that have very low indicators or, at all, are absent in the majority of Russian regions. In turn we will note that activity of the majority of sectors of economy which use buildings, constructions and other building constructions is based on results of construction. Construction can become the fertile field for realization and introduction of innovative projects, technologies and developments and also construction materials. Now the organizations, whose primary activity is - construction are actively created and work in each region of the Russian Federation.

The world financial and economic crisis has seriously affected consumer ability of the population and legal entities in the sphere of real estate that has resulted in unprofitability and considerable reduction of the number of construction organizations from 2013 to 2015. However in the majority of regions of the CFD the minimum positive dynamics in restoration of a number of the companie's data in 2016 is observed.

We will note that in 2016 a share of construction organizations in regions of the CFD in the structure of all enterprises has grown to $4,5 \%$ that is $1,2 \%$ lower than this indicator across Russia in general $(5,7 \%)$, and the contribution of this kind of activity to size GRP averages $9,75 \%$ in the same areas.

The dynamics for 2014-2016 demonstrate a decrease in the amount of work, executed by the economic activity form called "Construction", and their shares in GRP of regions. The general dynamics in construction are characterized by a negative tendency in recent years that is connected with a considerable rise in prices for importing construction materials and also with a sharp decrease in the real located income of the population. In turn in $20164,5 \%$ of region's enterprises in the CFD which treat construction bring $10 \%$ of a gross regional product. The general ratio of a share of the construction enterprises and their contribution to GRP in regions is presented in figure 1.

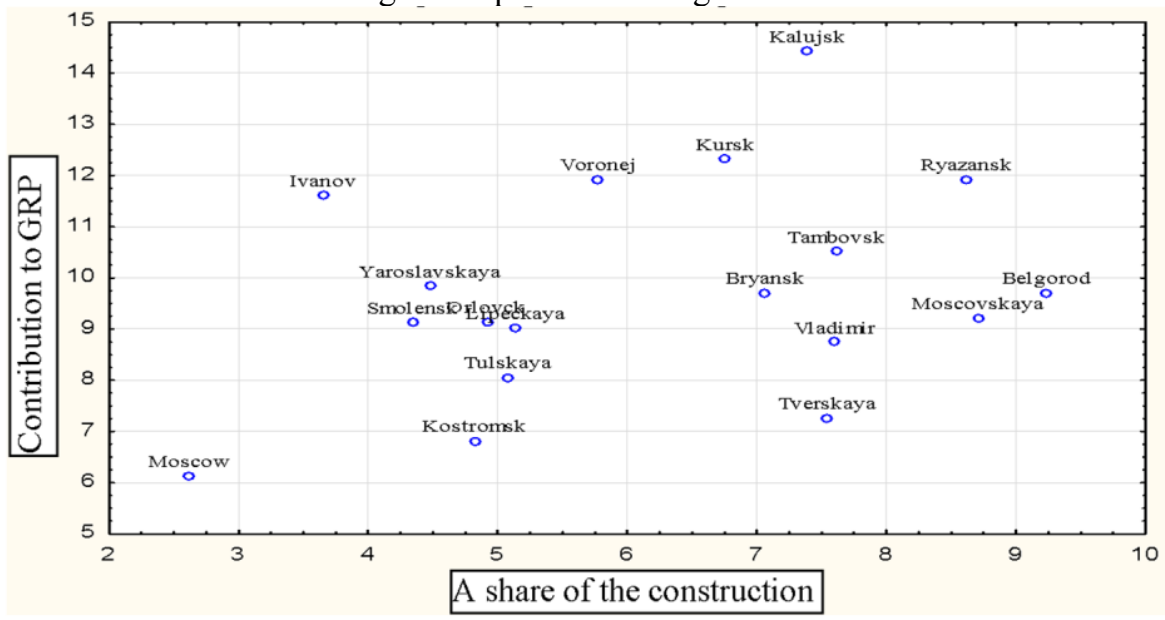

Fig. 1. A ratio of a share of the construction enterprises and their contribution to GRP in regions of the CFD in 2016.

Increase in a share of the construction organizations in regions most often leads to an increase in a share of volumes of construction works in GRP, that demonstrates the importance of this type of economic activity for the majority of regions in the CFD.

It is known that for successful functioning in the market of each organization it is necessary to introduce innovative developments in production and also to cooperate actively with various social partners. The considered data confirms the importance of activity of the construction organizations in social and economic development of the country. However, indicators of development of innovative activity in the sphere of 
construction occupy a small share from the total amount of innovative goods, work, services. So, according to researches of the Higher School of Economics [5] in 2015 the cumulative level of innovative activity of the construction organizations in Russia was only $2 \%$, meanwhile all organizations carried out only technological innovations (figure 2 ).

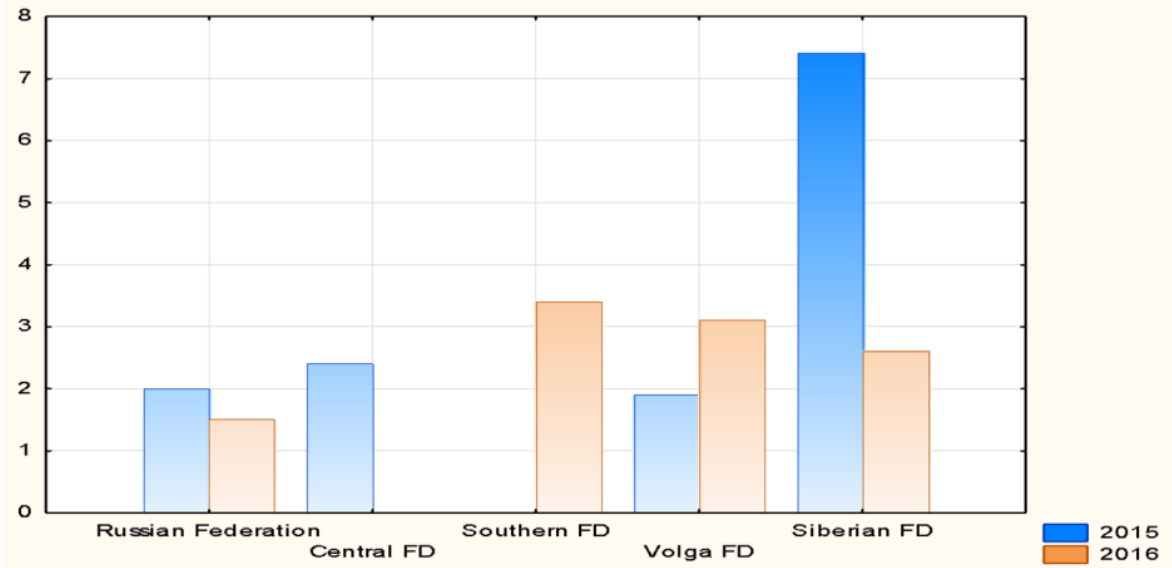

Fig. 2. Cumulative level of innovative activity of the construction organizations for the federal districts of the Russian Federation in 2015-2016, \%.

Apparently, the share of the innovation-active construction enterprises in Russia in 2016 has decreased by $0,5 \%$ and has made 1,5\%, at the same time in 2016 in the Volga Federal District $3,1 \%$ of the organizations carried out both technological, and organizational innovations, including 1,6\% - marketing ${ }^{\dagger}$.

Costs of the construction organizations of innovations in 2015 have made 13,3 million rubles, 12,1 million rubles out of which - installation of buildings and constructions from combined designs and 1,3 million rubles - production of other construction works, and in 2016 all 100\% - 6,3 million rubles - expenses belong to the production of other construction works, out of which 33,3\% - costs of research and development, and 66,7\% - costs of acquisition of machines and the equipment. At the same time the volume of innovative goods in 2016 was 2351 million rubles what makes 3,2 \% of total amount of the shipped goods, the performed work, services in construction.

The Vladimir region is chosen to define the reasons of low innovative activity of the enterprises of the construction sector, as the subject of research. It has the average level of economic development, investment attractiveness and the Russian regional innovative index among regions of Central Federal District in economic indicators.

The main competitive advantages of the Vladimir region are: successful location in relation to such large cities as Moscow, Nizhny Novgorod and Yaroslavl. A positive moment for implementing production activity is convenient transport connection and rich mineral resources of the region. The construction organizations of area make a wide range of materials, products and designs. In modern conditions for increase in competitiveness and also preservation of steady position the organizations need to apply innovative technologies and developments more and more.

\footnotetext{
$\dagger$ Grocery innovations in construction include the use of new construction materials having the increased operational and consumer qualities (heatpreserving, soundproofing, economic, etc.). Process innovations represent introduction of new effective construction technologies allowing to achieve more efficiency, decrease in terms of construction, etc.
} 
At the moment a lot of work on implementing the "Development of the Industry of the Vladimir Region, Increase in Its Competitiveness and Ensuring Import Substitution for 2015 - 2020" program is being done [6].

The Vladimir Economic forum is held annually for the sustainable and systematic development of the region's economy. In 2018, a day before the forum's official opening, the first discussion platform "Modernization of construction branch on the basis of innovative technologies" was passed on, forum's participants discussed innovative technologies in construction. In the beginning of the meeting the director of the regional department of construction and architecture, Dmitry Zolin, told about the main achievements in the construction branch of the Vladimir region. According to Zolin, the volume of the entered housing in five years (from 2012 to 2017) has increased by 1,4 times therefore there was a depreciation of square meter for $20 \%$. Also the quantity of the constructed social objects grows, 6,3 billion rubles have been allocated for these purposes for the reporting period from the budget. According to the director of the regional department of construction, in the area the market of mortgage lending is also restored [7].

The leaders in the field of innovative production on the territory of the Vladimir region are such companies as: STES-Vladimir and LLC Vertikal Product Company.

Now, when the top management of the country has sharply set the task of increase in power and thermal efficiency in national economy and economy to the modern European level, JSC STES-Vladimir Company became the first industrial production of unique construction material in Russia of the NEOPORM foamglass capable to effectively preserve energy without replacements and repairs during long-term. According to information provided on the website the Contractor Database follows from the report of the JSC STES-Vladimir Company that in 2016 sales have increased by 4,03 times to 528,53 million rubles from 131,17 million rubles in comparison with 2015 . The prime cost of production of the company has grown by 3,66 times to 897,97 million rubles. Net loss of the JSC STES-Vladimir Company for 2016 under RAS has decreased by 28,42 times to 38,91 million rubles from 1,11 billion rubles for the same period of last year. In 2015 sales volume has grown by 31,61 times to 131,17 million rubles from 4,15 million rubles for the same period of last year (from report of the company). The cost of products of the company for 2015 has grown by 71,62 times to 245,53 million rubles. Net loss of the company for 2015 has grown by $5,99 \%$ up to 1,11 billion rubles from 1,04 billion rubles for the same period of the previous year[8]. Increasing the demand by the construction organizations and housing and public utilities at heat-insulating material and also implementation of an auxiliary view of activity - construction of residential and uninhabited buildings, losses of JSC STES-Vladimir Company have allowed to lower considerably in 2016. [9]

Innovative production is provided to the construction organizations and by the LLC Vertikal Product Company. Here make translucent designs on the basis of aluminum profile systems which are actively used in various areas. In particular, the company has successfully executed an order for glazing of "Northern malls" in Vladimir. Its production was given preference when constructing facilities of the Moscow Metro. In a year the company produces up to 50 thousand square meters of aluminum designs. [10]

According to the information given by Rusprofile.ru the revenue for 2016 of the LLC Vertikal Product Company has increased from 127 million rubles up to 238 million rubles while profit has decreased from 4,1 million rubles to-11 million rubles. In 2015 the revenue of the company has increased from 74 million rubles up to 127 million rubles, profit has increased from 3,4 million rubles to 4,1 million rubles [11]. Decrease in net profit in 2016 is caused by overestimating of cost of net assets of the organization in 2015 up to 20 million rubles.

In activities of the construction organizations the key moment is the use of necessary raw materials and other materials. One of the largest producers of such materials - plywood 
and chipboard - is CJSC Murom. 150 thousand CBM of plywood, which are successfully functioning in the market for more than 85 years, annually releasing and 120 thousand CBM of wood-shaving plates. All shops are equipped with hi-tech innovative equipment produced in Germany, Japan and Finland. The production of the plant is exported to 32 countries of the world on three continents [12]. According to the information given by Rusprofile.ru revenue for 2015 has grown from 2600 million rubles to 3000 million rubles. Net profit has increased from 168 million rubles to 241 million rubles, and net assets of the organization have increased from 652 million rubles up to 790 million rubles [13].

The use of modern equipment, the use of innovative wood processing technologies and highly qualified employees of all segments of production and sales, enable to achieve such high performance of CJSC "Murom" and ensure the preservation of competitive positions in target markets in an ever-changing market environment [12].

The presented analysis of the activities of enterprises reflects a very small proportion of organizations working in the construction sector. But according to these results, we can say that the priority issues of innovations in construction are new technologies in the design of residential buildings, all social and production facilities, transport infrastructure, transport enterprises and controls, modern technologies, raw materials and other materials, highperformance equipment, management principles construction related to security, energy efficiency and environmental issues, which allow to reduce construction time without reducing the quality of delivery objects. Enterprises, the first to master competitive innovations, have the opportunity to reduce production costs and, accordingly, the cost of products sold.

The main economic objectives of enterprises are to reduce the estimated cost and reduce the duration of the construction cycle. However, quite often they are solved not by the introduction of high-tech projects, but by the use of cheaper analogues of building materials and unskilled labor. As analysis of general data by regions and country, as well as detailed on specific enterprises showed, companies that carry out construction activities rarely acquire innovative technologies, often using only new or improved building materials.

Within the framework of the survey, 520 top managers were interviewed by $15 \%$ of the construction companies in the Vladimir region for the main problems of their activities. The key topic of the survey was an analysis of the reasons preventing the introduction of innovative solutions in the construction industry. Based on the results of the study, the identified problems are grouped into four, the structure of which are presented in Figure 5.

Administrative and legal obstacles have noted $20 \%$ of respondents and have connected them first of all with insufficient standard and legal base (A1) and inconsistency of actions of self-regulatory organizations and the ministries of construction of the Russian Federation (A2), that often leads to increase in terms or non-performance of works. Lagging of normative and methodical documentation from the development of construction technologies (A3) often causes conflicts between design organizations, customers and contractors. The lack of privileges for the organizations which are engaged in innovative projects (A4) significantly reduces motivation to their introduction.

$55 \%$ of the respondents attributed the immunity of personnel organization to innovate (P1), depreciation of fixed assets and the lack of more modern alternatives at a reasonable price (P2) were added to the list of production. The shortcoming of experts of technical and environmental control of safety of innovative technologies at the enterprise leads to reduction of their introduction (P3). Also, one of the reasons is the lack of highly qualified personnel, starting with workers and ending with top managers who are able to work in a market environment and are not afraid of innovation (P4).

A large proportion of respondents $(70 \%)$ identified the most important economic reasons for low innovation activity. First of all, the leaders named the high cost of new technologies and materials (E1), which requires significant costs during the initial stage of 
construction and increases the payback period of investments. The second reason in this group is the low payment demand for construction products (E2), produced by new technologies not fully understood. According to managers, the people are used to and trust the proven traditional building materials, for example, brick or reinforced concrete, and often reasoned arguments in favor of advantageous alternative solutions are completely not perceived by customers. The third obstacle is high venture risks (E3), which reduce the investment attractiveness of the project, while there is weak financial support from the state. Also, this group includes high costs for training personnel working with innovative technologies (E4). Managers try to minimize these costs or shift to employees, fearing a possible dismissal of a trained worker.

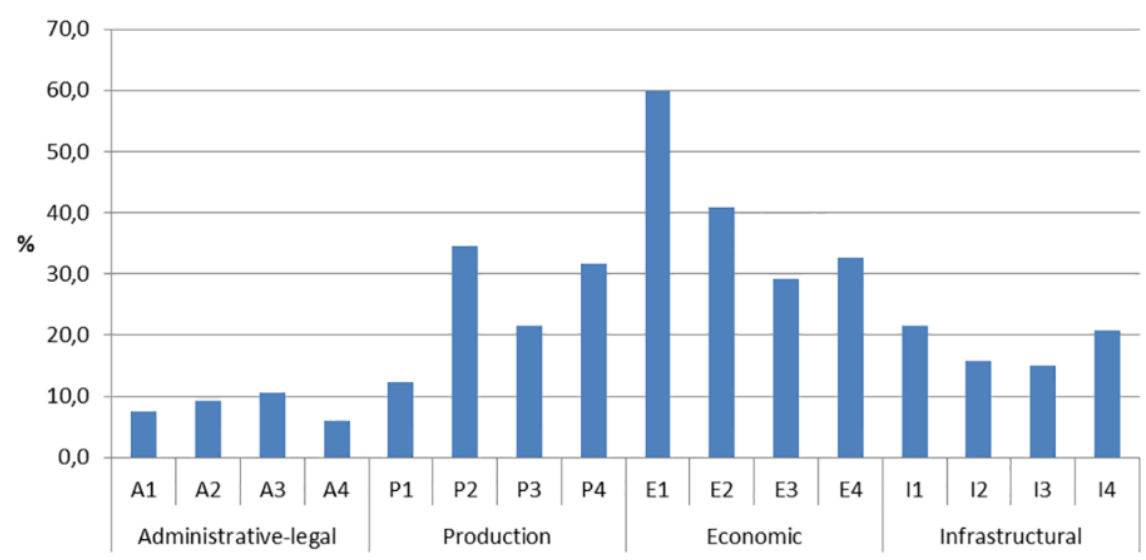

Fig. 2. Structure of the reasons interfering introduction of innovative solutions in activity of the construction organizations of the Vladimir region, \%.

A separate group of $25 \%$ of senior managers identified infrastructure reasons, including the lack of cluster (cluster) builders in the region, contributing to their effective interaction (I1) and the lack of innovation centers, business incubators and technology parks (I2). This problem also noted the lack of information on potential sales markets, innovations in technological processes and building materials (I3), which is often associated with a low possibility of cooperation with scientific and other organizations. Another problem of the construction industry in the Vladimir region, the respondents called the outflow of personnel (I4), including young, in the Moscow, Nizhny Novgorod and Yaroslavl regions. This aspect entails a reduction in the influx of new ideas and projects in the activities of construction organizations.

Note that similar problems of the construction industry are also given in the works of foreign authors [14-16] which indicate the typical nature of many reasons and the need for their comprehensive solution, including taking into account international experience.

\section{Conclusion}

As a result of the research, positive dynamics in the development of the construction industry in the regions of the central federal district, but low innovation activity of construction enterprises in the whole country and federal districts, in contrast to other economic activities were revealed. It should be noted that the introduction of innovative solutions in the construction sector, like any other sector of the Russian economy is a complex, complex task for all social partners. The use of innovative solutions in construction is relevant and important for the implementation of priority areas of state and regional programs aimed at improving the country's socio-economic development. 
The introduction of innovative technologies in the activities of construction organizations, for example, in the Vladimir region, is accompanied by a number of administrative, legal, industrial, economic and infrastructural problems, and requires significant financial investments and preparedness of administrative resources. However, in a temporary aspect, innovative projects contribute to saving costs and shortening the duration of the construction cycle, using more efficient construction materials and solutions from the economic and technical point of view. The fact that many innovations can improve the environmental, technical and fire safety of construction projects is important in modern society. Innovations allow construction companies to remain competitive leaders in their niche.

\section{References}

1. J. Schumpeter Theory of economic development. Capitalism, socialism and democracy (Eksmo, Moscow, 2007)

2. L.I. Goncharenko Dictionary of financial and economic terms (Financial university, Moscow, 2012)

3. N.V. Gorodnikova, L.M. Gokhberg, K.A. Ditkovsky, etc. Indicators of innovative activity: 2018: statistical collection; National. research. un-t Higher School of Economics (Higher School of Economics National Research University, Moscow, 2018)

4. Regions of Russia. Socio-economic indexes. 2017 (Rosstat, Moscow, 2017)

5. N. Gorodnikova, L. Gokhberg, K. Ditkovskiy et al. Indicators of Innovation in the Russian Federation: 2018 (National Research University Higher School of Economics, HSE, Moscow, 2018)

6. Russian Legal Portal. The resolution of administration of the Vladimir Region from 6/16/2015 № 562 "About the approval of the state program of the Vladimir region "Development of the industry of the Vladimir region, increase in its competitiveness and ensuring import substitution for 2015 - 2020" https://ipravo.info/vladimir1/acts/939.htm

7. Vladimir news. In Vladimir have discussed innovative technologies in construction http://vladimirnews.ru/fn_372486.html

8. Contractor database: Reporting of the companies. JSC STES-Vladimir Company, Vladimir region. https://www.k-agent.ru/catalog/3327823181-1053301282077

9. The official site of JSC "STES-Vladimir"/History of the company http://astess.com/about/history/

10. ESTP the Expert Construction Portal / News / the Innovative enterprises of the Vladimir region produce the advanced construction materials http://estpblog.ru/news/nid-3726/

11. Rusprofile.ru. Information on legal entities and individual entrepreneurs. LLC PF Vertikal https://www.rusprofile.ru/id/2421558

12. The official site of CJSC "Murom" / About the company http://www.zaomurom.ru/about/

13. Rusprofile.ru. Information on legal entities and individual entrepreneurs. CJSC "Murom" https://www.rusprofile.ru/id/3796636

14. Pui-Lam, A. Banaitis Organ., Techn. A. Manag. I. Constr. 9, 1528-1536 (2017)

15. D. G. Proverbs, G. D. Holt, and H. Y. Cheok Construction industry problems: the views of UK construction directors http://www.arcom.ac.uk/-docs/proceedings/ar2000073-081_Proverbs_Holt_and_Cheok.pdf

16. A-A. M. Okae Adow, S. E. Allotey, B. M. Arthur-Aidoo, IISTE, 3, 12 (2013) 